\title{
Analyzing drivers of fish biomass and biodiversity within community fish refuges in Cambodia
}

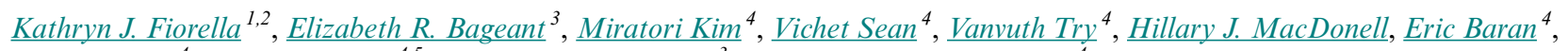

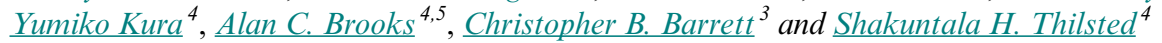

\begin{abstract}
Freshwater social-ecological systems are shaped by site-specific characteristics, environmental change and annual fluctuations, and the actions of resource users and managers. Our primary aim is to analyze the relative effects of these multifacted forces on fishery productivity and biodiversity using the case of community-managed protected areas within Cambodia's rice field fisheries, known as community fish refuges. Our secondary aim is to take advantage of fixed-effects regression models, a rigorous approach that is common in other disciplines, yet novel to analysis of social-ecological system productivity, and allows comparison of each site to itself across time using observational data. We analyze the relative associations of site characteristics, annual fluctuations, biophysical modifications (e.g., deepening, creation of inlet/outlets, etc.), and governance capacity (i.e., community committee meeting intensity, fundraising to support illegal fishing patrols, etc.) with fish biomass and biodiversity within 40 refuges over three years. We find that seasonal and site-specific effects within this system relate strongly to biomass and species richness patterns. We also find an association between biomass and biodiversity and some elements of governance capacity building. Our findings suggest that in this setting solutions tailored and responsive to the local context may be most appropriate given the strong interannual and site-specific drivers. Methodologically, the dynamism and site specificity of such systems befits within-site comparisons over long time horizons to appreciate the factors that drive biomass and biodiversity.
\end{abstract}

Key Words: coupled human and natural systems; freshwater fisheries; inland fisheries; Mekong River; protected areas; social-ecological systems; Tonle Sap Lake

\section{INTRODUCTION}

Where present, inland fisheries in poor countries provide a disproportionately large share of livelihoods and fish for local consumption relative to coastal fisheries (Cooke et al. 2016). Despite the importance of inland fisheries, the extent of inland catch has been underappreciated for decades (Fluet-Chouinard et al. 2018) and the inland fisheries sector is widely afflicted by management and restoration challenges, and competing uses for freshwater.

Freshwater protected areas, often called fish sanctuaries, represent an important management strategy to bolster fish production. However, the role and effectiveness of freshwater protected areas are underexamined. Remarkably few welldocumented examples of fish sanctuaries exist and developing country examples are even rarer, though freshwater protected areas have been established in Cambodia (Chheng 2010), India (Sarkar et al. 2013, Gupta et al. 2015), Laos (Baird 2000, Baird and Flaherty 2005), and the nations around Lake Victoria (Kiwango et al. 2013). Such community-managed inland protected areas often draw elements of their approach from a range of fishery management strategies, including adaptive comanagement (Kura et al. 2004, Olsson et al. 2004, Pomeroy and Andrew 2011, Ratner et al. 2012), agricultural landscape management (Dela Cruz et al. 1992, Gregory and Guttman 2002, Gurung and Wagle 2005), aquatic restoration (Zedler 2000, Society for Ecological Restoration International Science \& Policy Working Group 2004, Young et al. 2005), and marine protected areas (Gill et al. 2017).
Inland fisheries and community protected areas in particular represent an important yet inherently complex nexus of integration between natural systems, social systems, and their management. Ostrom's social-ecological systems framework is a tool to identify interactions among the governance system, a specific resource, and a resource system, or the ecosystem (Ostrom 2007, 2009) that facilities cross-system comparisons to identify key relationships and system components (McGinnis and Ostrom 2014). Such complex systems demand integrated analyses of social-ecological processes (Hughes et al. 2017) and new modeling approaches (Schlüter et al. 2012), but limited studies quantitatively integrate ecological components into socialecological systems analyses (Vogt et al. 2015). Research efforts that quantitatively analyze social-ecological system dynamics have generally analyzed components within the context of limited comparative sites (e.g, Laborde et al. 2016, Ziegler et al. 2017, Filbee-Dexter et al. 2018) or at a single time point (e.g., Leslie et al. 2015).

We have two research aims. First, we aim to analyze the interacting relationships between site characteristics, water quality, annual fluctuations in flood dynamics, and management actions taken by resource users and their association with fishery productivity and biodiversity in community-managed freshwater fish refuges. Our second aim is to apply a new approach to the quantitative analysis of social-ecological systems that extends the application of fixed effect regression models, commonly used in other disciplines, to study the productivity dynamics within a socialecological system.

${ }^{1}$ Department of Population Medicine and Diagnostic Sciences, Cornell University, ${ }^{2}$ Master of Public Health Program, Cornell University, ${ }^{3}$ Dyson School of Applied Economics and Management, Cornell University, ${ }^{4}$ WorldFish, ${ }^{5}$ Pact 
We analyze three years (2012-2015) of observational data on 40 community fish refuges (CFRs) in Cambodia's Tonle Sap floodplain using panel fixed effect regression models. Our analyses examine the impact of site-specific characteristics, seasonal and annual differences, and aggregated management actions designed to address governance capacity or provide for biophysical improvements. CFRs were adaptively managed, therefore we aggregate management intensity across governance capacity and biophysical improvement activities. Rather than examining individual actions, e.g., deepening ponds or committee meetings, we examine the suite of real-world activities as a whole, including deciding to act and selection of management strategies that plays out as resource users respond to changing environmental conditions. Our analyses rely on observational data, though repeated observations of the system enable us to account statistically for site characteristics and annual weather and flood fluctuations, e.g., exogenous annual effects of rainfall, flooding, temperature. Unlike much prior work on socialecological systems, we examine a large number of sites, track relationships over time, and compare each site to itself over time, allowing us to statistically account for the characteristics at each site that could otherwise confound the social-ecological relationships of interest.

\section{Cambodian fisheries}

The approximately 4.5 million Cambodians that work in the fisheries sector contribute $6-11 \%$ to national gross domestic product and depend on the annual flood for food and income (Asian Development Bank 2012, Hap et al. 2016). The rice field fisheries within the Tonle Sap Lake floodplain contributed $20 \%$ of annual fish production (550,000 metric tons) in 2013 (Hap et al. 2016). Rice field fisheries are embedded within a multifunctional agro-ecosystem that includes channels, lakes, and rivers and supports fish and other aquatic species (Balzer et al. 2006, Hap et al. 2016). A common pool resource, rice fields have been identified as a particularly important habitat for fisheries productivity and fish for consumption (Balzer et al. 2006). During the annual wet season, May through November, fish migrate from the lake and local tributaries to seasonally flooded rice fields to feed and breed (Campbell et al. 2006). From November to January, fish migrate back from rice fields and waterways to perennial water bodies, where they await the return of the rainy season in May (Campbell et al. 2006).

Concern for rice field fisheries' ability to meet the demands of a growing rural population led to the establishment of CFRs by the Government of Cambodia. CFRs are managed protected areas that are governed by community committees in conjunction with the Fisheries Administration, and located within rice field fisheries habitats (including rice fields, streams, channels, and lakes). As of 2013, there were 779 CFRs in the country (Fisheries Administration 2009). Fishing within CFRs is prohibited throughout the year so these perennial bodies of water can provide fish and other aquatic species with refuge during the dry season so that they can move out of the refuge during the wet season and increase fish catch in the surrounding area (Joffre et al. 2012). Our study focuses on 40 CFRs that received support from WorldFish and its partners from 2012 to 2016 to implement site-specific adaptive management actions to enhance fish production and diversity.

\section{METHODS}

Our analyses focus on isolating and describing relationships between CFR biomass and biodiversity and site characteristics, water quality, governance, and annual flood fluctuations. Figure 1 depicts our hypothesized determinants of CFR biomass and biodiversity and the potential relationships between them. We discuss each relationship in turn below.

Fig. 1. Conceptual diagram outlining the determinants of community fish refuge (CFR) biomass and biodiversity examined within our study. Feedbacks within the system are acknowledged through bidirectional arrows. For each number, we examine the relationship between the linked boxes, inclusive of upstream arrows (i.e., annual fluctuations are included within all models).

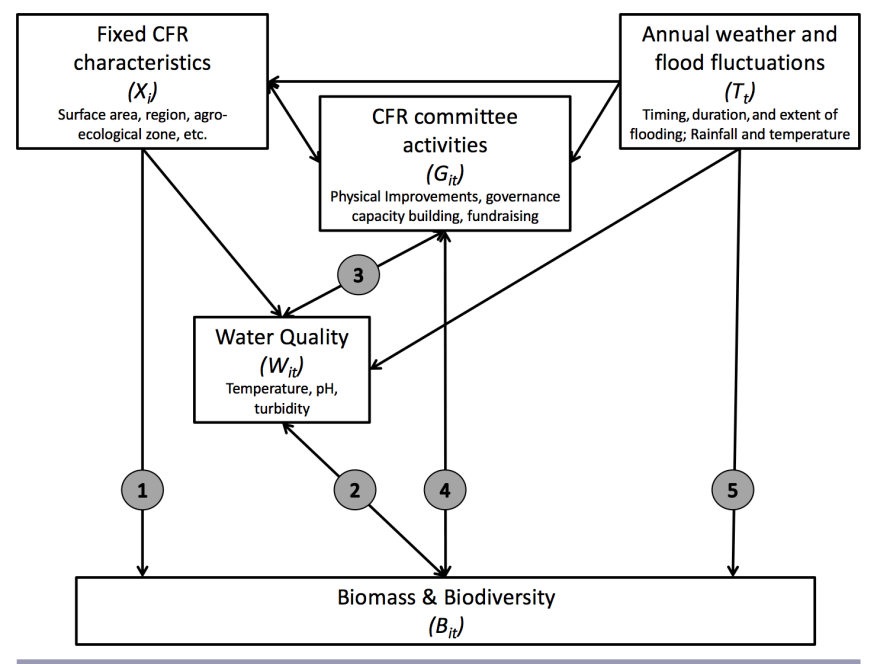

\section{Study site and WorldFish intervention}

Our study centers around 40 CFRs supported by WorldFish as part of the Rice Field Fisheries Enhancement Project (RFFEP), which was funded by USAID's Feed the Future program. The CFR sites were situated in the four provinces surrounding Tonle Sap Lake: Battambang, Kampong Thom, Pursat, and Siem Reap (Fi. 2). Through extensive consultation with community groups and fisheries experts at the start of the RFFEP project, four hydrologically distinct types of CFRs were identified: irrigation reservoirs, community ponds without flooding, community ponds with flooding, and segments of a large water body (Brooks et al. 2015). Site selection was done by WorldFish staff to capture diverse CFR types and informed by their assessments of likely success in project implementation and approximate representation across four CFR types and four provinces.

Management was responsive to user needs and perceptions (e.g., household preferences, user perceptions of the state of the fishery) and site characteristics (e.g., observed patterns of fish migration, hydrology) as identified through biomonitoring data on water quality, fish biomass surveys, and community perception. This adaptive management led to heterogeneous, tailored management approaches (Appendix 1; Brooks and Sieu 2016). Management actions included biophysical modifications aimed to improve water retention during the dry season, quality of fish habitat, and connectivity with rice fields (e.g., deepening of ponds, removal of 
vegetation, installation of brush parks, and creation of CFR inlet/ outlets and channels to rice field habitats) and were largely carried out during the dry season (Hortle et al. 2004). Governance support included assistance to CFR committees in developing intervention plans, electing representatives to governing committees, coaching on fundraising strategies, and implementing fishing prohibitions, demarcations, signage, and water use agreements; governance support also sought to improve coordination with local authorities (Joffre et al. 2012, Miratori and Brooks 2015). In addition, CFR committees and communities were provided with training regarding the rice field fisheries environment and its management, as well as capacity building in the areas of bookkeeping, financial planning, fundraising, and public speaking (Brooks and Sieu 2016). The management activities were based on WorldFish's longstanding research within the rice field fishery setting and project documentation provides detailed information about the conditions under which different activities were indicated (Hortle et al. 2004, Joffre et al. 2012, Miratori and Brooks 2015).

Fig. 2. Map of Community Fish Refuge sites (green dots) within the Tonle Sap Floodplain. The Tonle Sap Lake is represented in blue, dark gray lines represent provincial boundaries, and provinces included within the study and the capital of Phnom Penh are labeled.

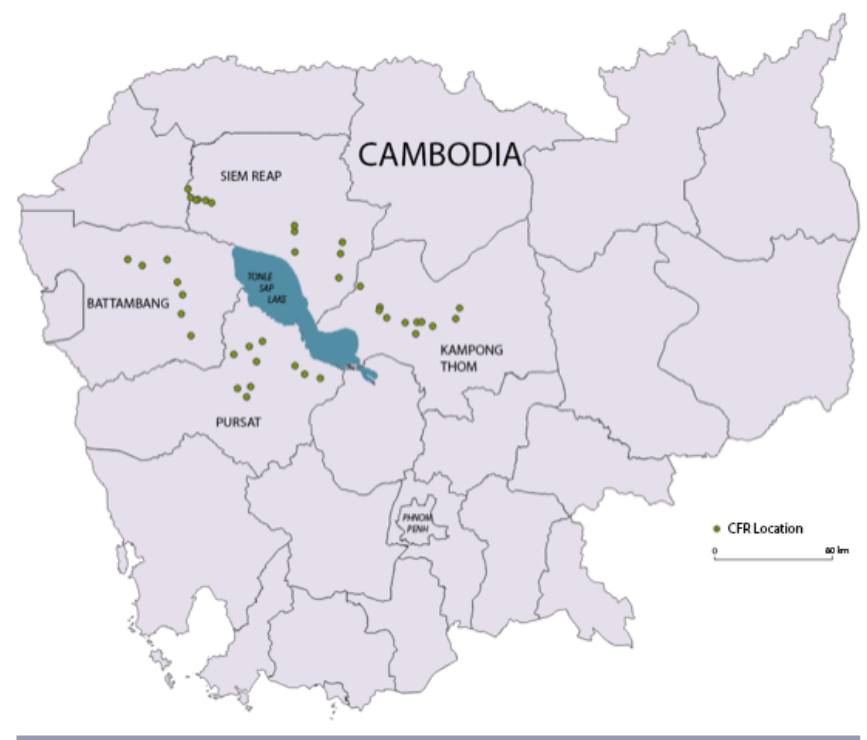

\section{Data sources and variable construction}

Three types of data were used for this analysis: (1) biomonitoring data; (2) intervention activities, biophysical and governance information; and (3) site characteristics. All data were collected by project staff at different time points and frequencies from 2012 to 2015 and made available to the authors by WorldFish.

Biomonitoring data were collected in February, May, August, and November from November 2012 through November 2015 and include water quality measurements and fish samples. Water quality data (nitrogen, phosphate, $\mathrm{pH}$, temperature, and turbidity) were obtained from $500 \mathrm{ml}$ water samples, taken midday between $11 \mathrm{~h}$ and $13 \mathrm{~h}, 10-20 \mathrm{~m}$ from shore and $30 \mathrm{~cm}$ below the surface in six locations around the CFR. Temperature was taken at each of the six water sample sites and then averaged. All six water samples were mixed in a bucket and a single sample of the mixture was used for $\mathrm{pH}$, phosphate, and nitrogen measurements. Limited variation in phosphate and nitrogen variables within the CFRs precluded their use in our analyses. Water quality variables used in the statistical models below were set to reflect optimal levels in tropical fish ponds and the values CFR managers were trained to recognize, with the variable being one if the measure falls in the defined range, zero otherwise: (a) $\mathrm{pH}$, normal range 6.5-8.5; (b) temperature, normal range $25-32^{\circ}$ $\mathrm{C}$, high range $>32^{\circ} \mathrm{C}$; and (c) Secchi depth, a measure of turbidity and phytoplankton productivity, normal range $30-45 \mathrm{~cm}$; a larger value indicating clearer water (Rouse 1979, USAID 2012, Dodds and Whiles 2010). These adjustments were made to account for the fact that increases in these variables are not uniformly problematic, but constitute a problem for fish health when they exceed a certain range. A binary variable was used because few measurements exceeded the acceptable ranges, meaning multiple bins would have few observations.

Fish samples were collected using gill nets. Pond size varied seasonally, as ponds contracted in the dry season, and sampling was responsive to these seasonal changes to avoid excessive sampling in small water bodies. In ponds larger than 0.35 hectares, long gill nets (18 $\mathrm{m}$ in length) were used, and in ponds less than 0.35 hectares, short gill nets ( $9 \mathrm{~m}$ in length) were used. Gill nettings were replicated eight times per time point, unless the pond was smaller than 0.25 hectares, in which case, five replicates were used. Both long and short gill nets were $2.5 \mathrm{~m}$ in height with alternating mesh sizes (e.g., $1.5 \mathrm{~m}$ length per mesh size in short gill net, $3 \mathrm{~m}$ length per mesh size in long gill net) of $1.5,2,4,6,8$, and $10 \mathrm{~cm}$ (Jensen 1990). Gill nets were set between $16 \mathrm{~h}$ and $17 \mathrm{~h}$ and remained in the water for 12-14 hours (Minns and Hurley 1988). The depth of the gill net was recorded and we used this to calculate the submerged net area. Fish caught were grouped by species and the number and total weight of fish of each species was recorded. At a given time point, the total number and weight of fish were summed across replicates to calculate biomass and biodiversity values; because methods were standardized across CFRs, effort was equivalent across sites and time points.

Using the biomonitoring data, we constructed two measures to understand the fish community: biomass and species richness (Magurran 2004). Biomass provides a measure of the quantity of fish and species richness describes the diversity of fish species, or biodiversity. Biomass was defined as the average weight of fish caught across gill net survey replicates per square meter of submerged gill net. Species richness refers to the number of species. To account for differences in sampling effort, in our analysis we defined species richness as the total number of species caught across gill net survey replicates. Because the species accumulation function was unknown in this setting and net area varied considerably, we did not adjust species richness by gill net area and instead explicitly controlled for submerged net area in models of species richness.

Intervention activities data were collated by calendar year from 2012 to 2015 . Because CFRs were adaptively managed by CFR committees, a variety of management actions were undertaken and we thus included biophysical modification and governance activities, which were coded as count variables within categories 
defined by WorldFish classifications on the nature of the activity, e.g., to address water quality and governance capacity building (Appendix 1).

Site characteristics were collected once in 2012 and considered fixed over time. Site characteristics included CFR type, surface area of the CFR in the dry season at baseline (e.g., minimum habitat size), location, and number of households associated with the CFR.

\section{Statistical methodology and variable construction}

To analyze the factors that are associated with CFR biomass and species richness, we used a combination of cross-sectional and panel linear regression models, including fixed effects models (Wooldridge 2001), where possible. CFR fixed effects regressions identified the associations between biomass or species richness and explanatory variables of interest using the within-CFR intertemporal variation, controlling for all time invariant differences among CFRs, both observed and unobserved. Our sample comprised 40 CFRs monitored over three years. Our data contain time-invariant (CFR characteristics), annual (CFR interventions, year), and seasonal (13 time points; water quality) variables. To compile and analyze data, we used $\mathrm{R}$ vegan package (Oksanen et al. 2019) and Stata version 14 (Stata 2017).

Species richness and biomass in CFR $i$, at time $t$, represented by $B_{i t}$, are conceptualized as a function of annual covariate flood, temperature, and rainfall fluctuations, $T_{t}$, that affect all CFRs; time-invariant CFR characteristics $X_{i}$; time-varying CFR governance and biophysical interventions, $V_{i t}$, and time-varying CFR characteristics such as water quality, $W_{i t}$ :

$B_{i t}=\mathrm{f}\left(\mathrm{T}_{t}, \mathrm{X}_{i}, \mathrm{~V}_{i t}, \mathrm{~W}_{i t}\right)$

We consider relationships 1, 2, and 3 from Figure 1 each in a separate regression model, and then examine relationship 4 in a model that simultaneously nests relationships 1,2 , and 3 . Relationship 5, also shown in Figure 1, is accounted for in all models as a vector of year indicator variables, $T_{t}$, the coefficient on which tell us the role of annual weather, flood, or other events experienced uniformly across the sample, while better isolating the other relationships. Specific regression models for each relationship are detailed in turn below. We aim to describe the interacting dynamics associated with biomass and biodiversity within the CFRs rather than identify causal relationships. Although our analysis provides the opportunity to assess factors potentially associated with CFR biomass and biodiversity, limitations include sample size, problems of multiple comparisons, the inability to specify multiple components of the biological community (biomass and species richness) within the same model, and the challenges of postintervention analysis using observational data.

Relationship 1: Site characteristics related to biomass and species richness

To understand the association between CFR characteristics (CFR category, province, agro-ecological zone, number of households, and CFR area) and biomass and species richness, we estimate a pooled ordinary least squares regression as follows:

$B_{i t}=\alpha+\beta_{1} \mathrm{C}_{i}+\beta_{2} \mathrm{P}_{i+} \beta_{3} \mathrm{E}_{i+} \beta_{4} \mathrm{H}_{i+} \beta_{5} \mathrm{Z}_{i+} \beta_{6} \mathrm{~N}_{i t} \beta_{7} \mathrm{~T}_{t+} \mathrm{e}_{i t}$
$C_{i}$ represents a vector of binary variables, each indicating one of the four CFR categories (community ponds without flooding, community ponds with flooding, and segments of a large water body, with irrigation reservoirs as the omitted reference category). $P_{i}$ is a vector of indicators for the province in which the CFR is located; and $E_{i}$ is a vector of binary variables representing agroecological zones (upland irrigated rice, upland crops/rainfed rice, rainfed lowland rice, with lowland deepwater rice as the omitted reference category). Agro-ecological zones are distinct from CFR type and describe the area surrounding the CFR. Additionally, population pressure on the CFR is captured by, $H_{i}$, which is the number of households living in the CFR's zone of influence at baseline, and baseline surface area of the CFR during the dry season is captured in $Z_{i}$. Finally, we included a vector of year indicators $\left(T_{t}\right)$ to capture annual drivers of biomass and species richness that are common to all CFRs, such as those caused by annual weather and flood variation. We expected that each of these factors would affect CFR biomass and biodiversity, with larger CFR size and smaller population having a positive impact but no a priori predictions for CFR type, province, or agroecological zone.

Because of population changes over time and intra-annual fluctuations of CFR size $\left(\mathrm{m}^{2}\right)$ depending on season and timing of rainfall, $H_{i}$ and $Z_{i}$ are likely measured with some degree of error, but we include them to control for vast background differences between CFRs' size and population base. When species richness is the outcome, we also include a control for the average submerged net area $\left(\mathrm{m}^{2}\right)$ during biomonitoring, $N_{i t}$, in order to account for net size adjustments in the biomonitoring sampling protocol.

We interpret coefficients $\beta_{1}-\beta_{6}$ as the conditional relationships between the respective variables and the outcome across all years and CFRs, on average. In this equation, $\alpha$ represents the $y-$ intercept, or the constant if all other variables are set to 0 , and $e_{i t}$ is the error term. Pooled ordinary least squares (OLS) regressions are particularly vulnerable to bias because of unobserved heterogeneity among the CFRs, therefore we favor the CFR fixed effects regressions below, which control for this heterogeneity. We present the results from Equation (2) as descriptive associations that highlight the importance of site-specific, time invariant characteristics that are statistically accounted for in the fixed effects regressions described below and further motivate the use of fixed effects analysis in the models that follow.

\section{Relationship 2: Water quality variables related to biomass and} species richness

To understand the impact of water quality on CFR biomass and species richness, we used a 13-period panel of biomonitoring data. Biomonitoring data was collected every three months and we model relationships of CFR $i$ at period $p$, where subscript $p$ represents three-month periods and differs from the annual $t$ subscript in model (2) above. We estimate the fixed effects regression $B_{i p}=\gamma_{1} \mathrm{~m}_{i, p}+\gamma_{2} \mathrm{~m}_{i, p-1}+\gamma_{3} \mathrm{P}_{i, p}+\gamma_{4} \mathrm{P}_{i, p-1}+\gamma_{5} \mathrm{~s}_{i, p}+\gamma_{6} \mathrm{~s}_{i, p-1}+\gamma_{7} \mathrm{~s}^{2}{ }_{i, p}+$
$\gamma_{8} \mathrm{~s}^{2}{ }_{i, p-1}+\gamma_{9} \mathrm{n}_{i, p}+\gamma_{10} \mathrm{O}_{p}+\mu_{i}+\varepsilon_{i, p}$

in which the outcome is a function of whether the water temperature was above $32{ }^{\circ} \mathrm{C}$ in the current period, $m_{i, p}$, and, 
because temperature effects may not always be immediate, in the previous period, $m_{i, p-1}$. Similarly, we included a binary indicator equal to one if the $\mathrm{pH}$ was in the ideal range in the current period, $P_{i, p}$, or in the previous period, $P_{i, p-1}$. Finally, we included continuous values of Secchi depth (cm), $s_{i p}$, and its square, $s_{i p}^{2}$, in the current and previous period ( $s_{i, p-1}$ and $s_{i, p-1}^{2}$, respectively). We included a square term for Secchi depth to account for diminishing returns to water clarity as it moves out of the ideal range (see Appendix 2 for summary statistics). We used the natural $\log$ of all Secchi depth values. We also included, when species richness was the outcome, a control for the average submerged net area during biomonitoring, $n_{i, p}$. We included a vector of month and year indicators, $O_{p}$, to control for seasonality, including the seasonal life cycles and growth patterns of fish. The composite error term consisted of $\mu_{i}$, the unobserved CFR effect, and $\varepsilon_{i, p}$, the idiosyncratic error. The fixed effects model allowed us to control for any time-invariant, unobservable CFR characteristics that may influence the outcomes of interest.

\section{Relationship 3: Management actions related to water quality}

To assess how management interventions impacted water quality, we modeled the relationship between water quality, $W_{i p}$, in CFR $i$ during period $p$ and biophysical interventions carried out by the CFR management committees in the preceding year. We estimated the following fixed effects regression:

$$
W_{i p}=\alpha_{\mathrm{i}}+\delta_{1} \mathrm{~V}_{\mathrm{i}, \mathrm{t}-1}+\delta_{2} \mathrm{Q}_{\mathrm{i}, \mathrm{t}-1}+\delta_{3} \mathrm{M}_{\mathrm{p}}+\delta_{3} \mathrm{~T}_{\mathrm{p}}+\mu_{i}+\varepsilon_{i p}
$$

Outcome variables, $W_{i p}$, are a binary indicator of whether the water temperature was $\geq 32{ }^{\circ} \mathrm{C}$, the natural log of Secchi depth $(\mathrm{cm})$, and a binary indicator of whether the $\mathrm{pH}$ levels fell into the ideal range (6.5-8.5 moles/liter). Binary outcomes are estimated as a linear probability model, using an OLS estimator with fixed effects. The model includes a count of CFR environment-related activities, $\mathrm{V}_{\mathrm{i}, \mathrm{t}-1}$, and a count of water quality activities, $\mathrm{Q}_{\mathrm{i}, \mathrm{t}-1}$. Note that all outcomes vary intra-annually, while some explanatory variables $\left(\mathrm{V}_{\mathrm{i}, \mathrm{t}-1}\right.$ and $\left.\mathrm{Q}_{\mathrm{i}, \mathrm{t}-1}\right)$ vary at the annual level only. We also included a vector of month and year indicators, $\left(M_{p}\right.$ and $\left.T_{p}\right)$, to control for seasonal and annual fluctuations common to all CFRs, including the seasonal life cycles and growth patterns of fish and covariate annual rainfall, temperature, and flood patterns. The composite error term consisted of $\mu_{i}$, the unobserved CFR effect and $\varepsilon_{i p}$, the idiosyncratic error. Again, we were able to estimate a CFR fixed effects model, allowing us to control for unobservable CFR characteristics. Outcomes in a given year were regressed on the activities of the prior year to ensure that interventions took place prior in time to outcomes.

Environment-related activities $\left(\mathrm{V}_{\mathrm{i}, \mathrm{t}-\mathrm{1}}\right)$ included building fences and ecoshelters, adding fertilizer, fingerlings, broodstock, adding or removing vegetation, expanding the CFR, planting flooded forests or purchasing a boat for monitoring and patrols (Appendix 1). Water quality related $\left(Q_{i, t-1}\right)$ activities included adding channels, inlets, outlets, and pumps, building dams, and deepening the CFR. Because CFR committees implemented activities in response to conditions within their CFR, our measure provided a real-world metric that captured the impact when CFR committees reacted to changes in their system, elected a sitespecific management action, and carried it out. The wide range of activities and frequencies CFR committees elected to implement were too low to disaggregate by individual activity. Consequently, we were not able to address the productivity effects of specific actions taken by CFRs.

\section{Relationship 4: Management actions related to biomass and biodiversity}

Finally, we examined the relationship between the governance and biophysical activities of the CFR committees and species richness and biomass, in effect nesting all of the preceding models. We estimated model (2), while controlling for CFR fixed characteristics (model 1) with a CFR fixed effect and included water quality controls as in model (3). We can then attribute any remaining association to relationship 4. In addition to controlling for unobserved physical characteristics, the CFR fixed effect controls for unobserved differences in CFR governance capacity. As governance actions were adaptive in response to local conditions, we characterized governance using a count variable, i.e., number of actions taken by the CFR committee, that allowed us to examine the composite effect of committees' decision to act, the selection of management action, and the outcome of those efforts. Although our characterization accounted for the realworld action taken by committees, it does restrict the inference we can make and individual management actions cannot be assessed.

$B_{i t}=\sigma_{1} \mathbf{V}_{i t}+\sigma_{2} \mathrm{Q}_{i t}+\sigma_{3} \mathbf{M}_{i t}+\sigma_{4} \mathrm{~A}_{i t}+\sigma_{5} \mathrm{~N}_{i t}+\sigma_{6} \mathrm{~W}_{i t}^{F}+\sigma_{7} \mathrm{~T}_{t}+\zeta_{i}+$ $\mathrm{e}_{i t} \quad(5)$

Outcome variables, $B_{i t}$, were aggregated by calendar year and regressed on count variables indicating the number of CFR activities in a given category in a given year. Activities were categorized into CFR environment-related activities $\left(V_{i t}\right)$ and water quality activities $\left(Q_{i t}\right)$ exactly as in model (4), but using the current period rather than the previous, as we did not have enough annual time periods to support analysis with annual lags. Additionally, $M_{i t}$ represents a count of various governance meetings, including awareness-raising events on multiple topics, coaching sessions on management skills, and reflection worskhops; $A_{i t}$, represents governance activities such as building a new CFR, demarcating the boundaries of the CFR, adding signs, paths, guard infrastructure, holding elections of CFR committees, establishing bylaws, holding events, organizing savings groups, and integrating CFR actions into broader community investment plans (Appendix 1). These sets of variables reflect the categorizations made by WorldFish staff in communications with CFR managers. As in model (2), $N_{i t}$ is included for all species richness regressions to explicitly control for the area of net submerged during biomonitoring data collection $\left(\mathrm{m}^{2}\right)$. We included $W^{F}$, a vector of water quality variables from February of each year, the month in which we would expect the poorest water quality because of lack of rainfall during the dry season, so that we can interpret $\sigma_{1}-\sigma_{4}$ as the relationship between each activity, independently of water quality.

\section{RESULTS}

Descriptive statistics for the CFRs $(n=40)$ across all years $(2012$ 2015) are reported in Appendix 2 and a summary of results is provided in Appendix 3. 
Table 1. Relationships between community fish refuge (CFR) characteristics and biomass and species richness. The results from longitudinal regression models of relationship 1, which examines the association between CFR characteristics and the quantity of fish, or biomass, and biodiversity, or species richness, of those fish from 2012 to 2015.

\begin{tabular}{|c|c|c|c|c|}
\hline & \multicolumn{2}{|c|}{$\begin{array}{c}\text { Biomass } \\
\left.\text { (ln } \mathrm{kg} \mathrm{catch} / \mathrm{m}^{2} \text { gillnet }\right)\end{array}$} & \multicolumn{2}{|c|}{$\begin{array}{c}\text { Species Richness } \\
\text { (number of species) }\end{array}$} \\
\hline & Coeff. & Std. Error & Coeff. & Std. Error \\
\hline $1=$ Community Pond without Flooding ${ }^{\dagger}$ & $0.403 * *$ & $(0.196)$ & -0.457 & $(1.382)$ \\
\hline $1=$ Community Pond with Flooding ${ }^{\dagger}$ & 0.206 & $(0.282)$ & 0.300 & $(2.003)$ \\
\hline $1=$ Segment of Large Water Body ${ }^{\dagger}$ & -0.171 & $(0.223)$ & -1.102 & $(1.559)$ \\
\hline $1=$ Kampong Thom Province ${ }^{\star}$ & -0.0780 & $(0.175)$ & $-3.017 * *$ & $(1.240)$ \\
\hline $1=$ Pursat Province & $-0.617 * * *$ & $(0.167)$ & $-7.661 * * *$ & $(1.154)$ \\
\hline $1=$ Siem Riep Province ${ }^{*}$ & $-0.705^{* * *}$ & $(0.174)$ & -1.113 & $(1.231)$ \\
\hline $1=$ Rainfed lowland rice $A E Z^{\S}$ & $0.396^{* *}$ & $(0.171)$ & $2.819 * *$ & $(1.196)$ \\
\hline $1=$ Upland Irrigated AEZ $Z^{\S}$ & 0.0106 & $(0.224)$ & -0.629 & $(1.630)$ \\
\hline $1=$ Upland Crop/Rainfed Rice AEZ ${ }^{\S}$ & 0.188 & $(0.201)$ & 0.995 & $(1.427)$ \\
\hline (ln) Number of Households in CFR Catchment Area & -0.0840 & $(0.0725)$ & -0.554 & $(0.518)$ \\
\hline (ln) CFR Surface Area in Dry Season (Ha) & $-0.279 * *$ & $(0.116)$ & $1.709 *$ & $(0.880)$ \\
\hline Area of Gill Net Submerged During Biomonitoring Sampling $\left(\mathrm{m}^{2}\right)$ & & & $0.0914^{*}$ & $(0.0518)$ \\
\hline Year 2013 & 0.0356 & $(0.136)$ & $-2.744 * * *$ & $(0.937)$ \\
\hline Year 2014 & 0.188 & $(0.136)$ & $-2.409 * *$ & $(0.939)$ \\
\hline Year 2015 & 0.213 & $(0.136)$ & $-3.045 * * *$ & $(0.938)$ \\
\hline Constant & $4.253^{* * *}$ & $(0.535)$ & $19.36^{* * *}$ & $(3.712)$ \\
\hline Observations & 160 & & 160 & \\
\hline R-squared & 0.428 & & 0.420 & \\
\hline
\end{tabular}

Notes: CFR type, province and agro-ecological zone are all binary variables. Reference categories are as follows: ${ }^{\dagger}$ Reference category is "Irrigation

Reservoir"; "Reference category is Battambang Province; ${ }^{\S}$ Reference category is "lowland deepwater rice" Agro-Eco Zone. Reference year is 2012.

Standard errors in parentheses. Significance levels: $* * * p<0.01, * * p<0.05,{ }^{*} p<0.1$.

\section{Relationship 1: Site characteristics related to biomass and species richness}

To understand the site characteristics that correlate with biomass and biodiversity across CFRs, we estimated via pooled OLS regression the conditional associations with CFR category, agroecological zone (AEZ), number of households, CFR size, and year (Table 1).

In community ponds without flooding, biomass is significantly higher relative to irrigation reservoirs. CFRs in Battambang province had greater biomass compared to CFRs in Pursat and Siem Reap, and greater species richness than CFRs in Kampong Thom and Pursat. CFRs in rainfed lowland rice agro-ecological zones had significantly higher biomass and species richness compared to those in lowland deepwater rice agro-ecological zones. Larger CFR area during the dry season was associated with lower biomass and higher species diversity. Finally, species richness was systematically higher in 2012 (reference year) compared to the three years that followed. An alternate model that estimates these relationships separately by year is available in Appendix 4.

The effect sizes of our coefficient estimates represented an increase or decrease in the log of kilograms fish caught per meter squared of gillnet (biomass) and the number of species (species richness). Thus, the effect sizes we found of approximately $0.2-$ 0.7 in biomass and 1.7-7 in biodiversity represent a biologically meaningful difference in these metrics. For reference, the annual mean $\log \mathrm{kg}$ catch $/ \mathrm{m}^{2}$ was 3.52 , with a standard deviation of 0.77 , while mean species richness was 14.6 , with a standard deviation of 5.2 .
Relationship 2: Water quality variables related to biomass and species richness

Using fixed effects for CFR and time period to account for observable and unobservable time-invariant site-specific features of CFRs, some of which emerge above, we found significant relationships between biomass with seasonal (month) and annual effects when controlling for differences in water quality in the current and previous periods (Table 2). Within CFRs, species richness was significantly lower in August and November, compared to February. Within CFRs, biomass was significantly lower in May and August and significantly higher in November, compared to February. Species richness was significantly higher in 2015, compared to 2013 .

We also find associations between biomass and water quality in the previous period (Secchi depth, high water temperature, $\mathrm{pH}$ ). In the previous period, $\mathrm{pH}$ in the ideal range and a high water temperature were negatively associated with species richness. Although the $\mathrm{pH}$ result is counterintuitive, the large majority of $\mathrm{pH}$ readings were in the ideal range (Appendix 1). Previous period Secchi depth was positively associated with biomass, with diminishing marginal effects.

Relationship 3: Management actions related to water quality Using fixed effects for CFR, we found very limited evidence of relationships between activities designed to benefit CFR water quality or environment and dimensions of water quality (Table 3). We use a broad measure of management activities, a count of biophysical interventions that influence CFR water quality or CFR environment in the previous period. We found that the year 2015 was negatively associated with high water temperature and 
Table 2. The relationship between water quality indicators and community fish refuge (CFR) biomass and biodiversity. Using longitudinal regression models that include fixed effects for the month, year, and CFR, we show relationships between the role of water quality characteristics in the current and previous periods ("lagged" values below) and biomass and species richness in CFRs. "ln" refers to the natural log.

\begin{tabular}{|c|c|c|c|c|}
\hline & \multicolumn{2}{|c|}{$\begin{array}{c}\text { Biomass } \\
\left.\text { (ln } \mathrm{kg} \mathrm{catch} / \mathrm{m}^{2} \text { gillnet }\right)\end{array}$} & \multicolumn{2}{|c|}{$\begin{array}{l}\text { Species Richness } \\
\text { (number of species) }\end{array}$} \\
\hline & Coeff. & Std. Error & Coeff. & Std. Error \\
\hline $1=$ Water temperature $\geq 32^{\circ} \mathrm{C}$ & 0.407 & $(0.521)$ & -0.0207 & $(0.106)$ \\
\hline High water temp, lagged & $-1.095 * *$ & $(0.419)$ & -0.132 & $(0.0934)$ \\
\hline $1=\mathrm{pH}$ range $6.5-8.5$ & 0.380 & $(0.405)$ & -0.0203 & $(0.0837)$ \\
\hline Ideal $\mathrm{pH}$, lagged & $-1.078 * *$ & $(0.501)$ & -0.0736 & $(0.0946)$ \\
\hline Secchi depth, ln & 0.339 & $(0.771)$ & 0.177 & $(0.232)$ \\
\hline Secchi depth, ln, lagged & $3.344 * * *$ & $(0.713)$ & -0.112 & $(0.172)$ \\
\hline Secchi depth squared, ln & $0.260^{*}$ & $(0.152)$ & -0.0269 & $(0.0376)$ \\
\hline Secchi depth squared, ln, lagged & $-0.230^{*}$ & $(0.134)$ & 0.0430 & $(0.0288)$ \\
\hline Area $\left(\mathrm{m}^{2}\right)$ of gill net submerged & -0.0292 & $(0.0351)$ & & \\
\hline May & $-2.408 * * *$ & $(0.516)$ & -0.147 & $(0.0889)$ \\
\hline August & $-2.080 * * *$ & $(0.606)$ & $-0.744 * * *$ & $(0.101)$ \\
\hline November & $1.099 * *$ & $(0.515)$ & $-0.391 * * *$ & $(0.0885)$ \\
\hline 2014 & 0.278 & $(0.514)$ & 0.128 & $(0.0851)$ \\
\hline 2015 & -0.0435 & $(0.479)$ & $0.197 * *$ & (0.0920) \\
\hline Constant & $3.743^{*}$ & $(1.880)$ & $3.258 * * *$ & $(0.497)$ \\
\hline Observations & 477 & & 477 & \\
\hline R-squared & 0.353 & & 0.220 & \\
\hline
\end{tabular}

Robust standard errors in parentheses.

$* * * \mathrm{p}<0.01, * * \mathrm{p}<0.05, * \mathrm{p}<0.1$.

Reference month is February. Reference year is 2013.

positively associated with ideal $\mathrm{pH}$, and that the number of activities intended to improve water quality appears to be negatively associated with ideal $\mathrm{pH}$. However, we cannot conclude definitively that management activities did or did not impact water quality. Further, management activities might be important in forestalling waning water quality as opposed to improving water quality, and within this observational study we are unable to disentangle this possible effect.

\section{Relationship 4: Management actions related to biomass and species richness}

Using fixed effects for CFR, we examined the relationship between CFR activities, governance, and fundraising while controlling for water quality and annual effects (Table 4). Meetings held to coach or enhance knowledge were positively associated with species richness, though the effect size was small. CFR fundraising is positively associated with biomass. See Appendix 5 for logit and probit estimates of the same model.

\section{Relationship 5: Annual weather and flood fluctuations}

We found a broad influence of exogenous seasonal and annual weather and flood variations across the biophysical elements of CFRs. The relationship of seasonal and annual weather and flood variations is accounted for in all models. Seasonal patterns within the floodplain were responsible for changing biomass and species diversity, independent of water quality, throughout the course of the year from the dry season beginning around December and ending in April to the connectivity from CFRs to the rice fields in May to November. Further 2015 emerged as a particularly unique year (Tables 2, 3, 4). However, the site and water quality characteristics that influence biomass and biodiversity differed across years, suggesting, as predicted, that annual covariate effects may strongly shape this system (Appendix 4).

\section{DISCUSSION}

The rice field fisheries environment is home to a tremendous diversity of fish and aquatic species and supports access to food and livelihoods (Baran et al. 2014). Our results demonstrate that within CFRs, biomass and biodiversity of these inland protected areas are associated with season, annual weather, and flood fluctuations, and characteristics of the CFR site, i.e., province, agro-ecological zone, and surface area. Independently of these important characteristics, elements of CFR governance, e.g., fundraising or governance meetings, are associated with species richness and biomass. Our findings shed light on the function of inland protected areas in dynamic environments and suggest a strong role of seasonal, annual, and site-specific factors.

Previous quantitative analyses of social-ecological systems have used linear regressions (Leslie et al. 2015), random forest (Gill et al. 2017), structural equation modeling (Filbee-Dexter et al. 2018), and modeling projected results (Ziegler et al. 2017). Our analytic approach of fixed effects panel regression models is widely used in economics and other disciplines (Wooldridge 2001) but represents a novel approach to analyzing social-ecological systems. It extends the quantitative analysis to investigate the productivity of the CFR social-ecological systems through comparison of each site to itself across time. Because socialecological systems rarely present the opportunity for controlled experiments, our approach allows for comparisons of each site to itself over time to identify generalizable trends with observational data.

Our analysis highlights that the drivers of diversity and productivity within inland protected areas may vary annually. For example, comparisons of the site characteristics of CFRs across multiple years indicate that particular provinces, agro-ecological 
Table 3. Relationship between community fish refuge (CFR) water quality indicators and previous year habitat management actions. Using longitudinal regression models that include fixed effects for the CFR, we show relationships between the number of management activities undertaken to improve the CFR environment and water quality in the previous year ("lagged" values below) and the current water quality indicators in CFRs. "ln" refers to the natural log.

\begin{tabular}{|c|c|c|c|c|c|c|}
\hline & $\begin{array}{c}\text { Water Temperature } \\
\geq 32{ }^{\circ} \mathrm{C} \\
\end{array}$ & (ln) Secch depth & $\begin{array}{c}\text { Ideal } \mathrm{pH} \text { range } \\
6.5-8.5 \\
\end{array}$ & & & \\
\hline & Coeff. & Std. Error & Coeff. & Std. Error & Coeff. & Std. Error \\
\hline $\begin{array}{l}\text { Number of CFR } \\
\text { environment activities } \\
\text { (lagged) }\end{array}$ & 0.00712 & $(0.0151)$ & -0.00855 & $(0.0251)$ & 0.0364 & $(0.0258)$ \\
\hline $\begin{array}{l}\text { Number of water quality } \\
\text { activities (lagged) }\end{array}$ & -0.0188 & $(0.0280)$ & 0.0348 & $(0.0474)$ & $-0.0743^{*}$ & $(0.0391)$ \\
\hline Year $=2015$ & $-0.0705^{*}$ & $(0.0416)$ & -0.00123 & $(0.0675)$ & $0.0855^{*}$ & $(0.0507)$ \\
\hline May & $0.263 * * *$ & $(0.0478)$ & $-0.563 * * *$ & $(0.100)$ & $-0.163^{* *}$ & $(0.0610)$ \\
\hline August & $0.138 * * *$ & $(0.0404)$ & -0.113 & $(0.150)$ & 0.100 & $(0.0657)$ \\
\hline November & -0.0250 & $(0.0176)$ & $0.200^{*}$ & $(0.108)$ & 0.0750 & $(0.0640)$ \\
\hline Constant & 0.0553 & $(0.0380)$ & $3.295 * * *$ & $(0.0979)$ & $0.543^{* * *}$ & $(0.0723)$ \\
\hline CFR Fixed Effects & Yes & & Yes & & Yes & \\
\hline Observations & 320 & & 320 & & 320 & \\
\hline R-squared & 0.161 & & 0.155 & & 0.086 & \\
\hline Number of CFRs & 40 & & 40 & & 40 & \\
\hline \multicolumn{7}{|c|}{$\begin{array}{l}\text { Robust standard errors in parentheses. } \\
* * * \mathrm{p}<0.01, * * \mathrm{p}<0.05, * \mathrm{p}<0.1 \\
\text { Reference month is February. Reference year is } 2014 \text {. }\end{array}$} \\
\hline
\end{tabular}

zones, and surface area are associated with fish productivity and biodiversity (Table 1). However, comparing site characteristics in only a single year results in different characteristics emerging as significant in different years, e.g., rainfed lowland rice agroecological zone in 2012, CFR surface area in 2015 (Appendix 4). Within these dynamic social-ecological systems, accounting for strong site and annual effects over the longest time horizon possible is thus necessary to assess how shifting elements of their management, including habitat quality, biophysical changes, and governance, shape outcomes over time.

In our results, evidence as to whether the intensity of CFR management activities is associated with biomass or species richness within CFRs, however, is limited. Purposive site selection based on likelihood of success potentially introduces bias in observational data, potentially biasing our results toward a positive effect of management actions, and the absence of this finding thus strengthens the likelihood of there being no effect. However, limitations in our ability to detect a relationship due to imprecision and measurement error in intervention variables or too short a time period of study to observe associations are also possible explanations.

The absence of an effect between CFR biophysical management activities and biomass or species richness could also be due in part to the challenges in tailoring management actions to a particular setting. The extent to which management intensity should be linked to improved outcomes is difficult to predict because those sites with more management actions might also be facing more challenges or working harder to forestall declining biomass, obscuring a potential relationship. There may also be a mismatch between the intent of the resource managers, e.g, to improve water quality, and the outcome of their efforts. Although managers responded to what they observe and understand about their system and were provided technical support and tools to monitor water quality, identifying and carrying out appropriate management is complex and may have idiosyncratic outcomes. Actions that have a positive effect in one protected area may have a neutral or negative impact on productivity in another. Further, the productivity of social-ecological systems over time is entwined in the bidirectional feedbacks between natural system conditions and resource manager actions that respond to them, and thereby cyclically change natural conditions.

The positive associations we do observe between governance capacity building suggest that strengthening management capacity and motivating management investment in inland protected areas is of value. These mechanisms further provide for community-led adaptive management, whereby community members respond to changing environmental conditions and alter their management strategies. Although strong site-specific and annual effects may mean that detecting effects of management efforts within CFRs may be challenging or that their effects may be minimal relative to seasonal changes, the implementation of the CFR itself may still increase the productivity of the surrounding rice field fisheries, which we do not measure here. Analysis of the benefits of CFRs for fishery productivity and particularly to local populations are important next steps.

Our three-year time period, while longer than most previous studies of inland protected areas, may not be long enough to fully assess the impact of committee actions on the productivity of this dynamic inland ecosystem where CFRs may foster fish recruitment over longer time horizons. Other studies have found that it can take from 3 to 10 years before self-sufficient community organizing is in place to support sustainable fisheries management (Pomeroy and Berkes 1997, Pomeroy and Carlos 1997), and that observing effects of protection on marine species may take more than five years (Babcock et al. 2010). Further, the planning of a no-take reserve has also increased fishing pressure prior to 
Table 4. Relationships between governance actions and community fish refuge (CFR) biomass and biodiversity. Using longitudinal regression models that include fixed effects for the CFR, we show relationships between the number of governance activities, governance meetings, and the quantity of funds raised in the previous year ("lagged" values below) and the current biomass and species richness in CFRs. Our models also control for the CFR activities related to the environment and water quality, as well as water quality and year. "In" refers to the natural log.

\begin{tabular}{|c|c|c|c|c|}
\hline & \multicolumn{2}{|c|}{$\begin{array}{c}\text { Biomass } \\
\left(\ln \mathrm{kg} \mathrm{catch} / \mathrm{m}^{2} \text { gillnet }\right)\end{array}$} & \multicolumn{2}{|c|}{$\begin{array}{l}\text { Species Richness } \\
\text { (number of species) }\end{array}$} \\
\hline & Coeff. & Std. Error & Coeff. & Std. Error \\
\hline Number of CFR activities relating to the CFR environment & -0.00900 & $(0.0367)$ & -0.112 & $(0.177)$ \\
\hline Number of CFR activities relating to water quality & 0.0290 & $(0.0556)$ & 0.157 & $(0.353)$ \\
\hline $\begin{array}{l}\text { Number of CFR governance meetings, coaching and awareness } \\
\text { activities }\end{array}$ & 0.0268 & $(0.0331)$ & $0.475 * * *$ & $(0.153)$ \\
\hline Number of CFR governance activities & -0.0390 & $(0.0327)$ & $-0.308 * *$ & $(0.134)$ \\
\hline (ln) Total amount fundraised in USD & $0.0353^{*}$ & $(0.0200)$ & -0.0201 & $(0.117)$ \\
\hline $\begin{array}{l}1=\mathrm{pH} \text { in } 6.5-8.5 \text { range for at least } 1 \text { period in previous year } \\
\text { (calendar year) }\end{array}$ & -0.0744 & $(0.120)$ & 1.258 & (1.141) \\
\hline $1=$ Water temperature $\geq 32^{\circ} \mathrm{C}$ in February & $-0.246^{* *}$ & $(0.111)$ & -1.119 & $(1.125)$ \\
\hline (ln) Secchi in February & -0.000655 & $(0.00286)$ & 0.0136 & $(0.0186)$ \\
\hline Area of Gill Net Submerged During Biomonitoring Sampling $\left(\mathrm{m}^{2}\right)$ & & & 0.0417 & $(0.0913)$ \\
\hline Year $2014^{\dagger}$ & -0.0405 & $(0.129)$ & 0.0658 & $(0.705)$ \\
\hline Year $2015^{\dagger}$ & -0.0927 & $(0.135)$ & $-1.345^{*}$ & $(0.734)$ \\
\hline Constant & $3.565 * * *$ & $(0.259)$ & $10.76 * * *$ & $(2.680)$ \\
\hline CFR Fixed Effects & Yes & & Yes & \\
\hline Observations & 119 & & 119 & \\
\hline R-squared & 0.120 & & 0.176 & \\
\hline Number of cfrid & 40 & & 40 & \\
\hline
\end{tabular}

Robust standard errors in parentheses.

Significance levels: $* * * \mathrm{p}<0.01, * * \mathrm{p}<0.05, * \mathrm{p}<0.1$.

${ }^{\dagger}$ Reference year is 2013 .

implementation (McDermott et al. 2019), a dynamic that could alter the baseline biomass. These areas are ripe for future explorations of the relationships between interventions in inland protected areas and key outcomes, using precisely tracked interventions over an even longer time period than we offer here.

Our findings demonstrate the annual and seasonal effect of the flood pulse system on sites within the Tonle Sap floodplain. The established role of the flood pulse system in driving system productivity (Kummu and Sarkkula 2008) and biodiversity (Thomas et al. 2017) is particularly highlighted by the patterns seen in year 2015. In 2015, the flood arrived late and it was the start of an El Niño year, which has been shown to affect the annual flood dynamics (Ward et al. 2016). For several CFRs, the annual flooding failed to connect some CFRs and rice fields to the Tonle Sap Lake and other large water bodies, with some communities anecdotally reporting that fish from their CFRs were instrumental in providing for fish catch within rice fields. CFRs and fishery management in this dynamic system could play an important role in forestalling declines in water quality or resolving water user disputes in variable or bad years. However, CFRs function within the flood pulse system and are unlikely to be a viable management strategy if the system is broadly disrupted by irrigation or dam development along the Mekong River because disruption of the annual flood-pulse will prevent flooding waters from reaching CFRs and disrupt connectivity within the system (Lamberts and Koponen 2008, Arias et al. 2014).

\section{GROUNDED SPECULATION AND CONCLUSIONS}

Our findings highlight the important role of site-specific and seasonal characteristics in shaping social-ecological systems.
Although successful elements of biophysical changes and governance may not always be identifiable, equipping local communities to monitor their social-ecological systems and with opportunities to strengthen adaptive management holds considerable promise for sustainable social-ecological systems. In the context of complex, data-poor ecosystems in developing countries, resource users who know the natural systems, and the environmental and economic changes they face are often best positioned to respond quickly to changing conditions and elect appropriate management actions. The integration of technical interventions, governance, and capacity building to support these fishers is particularly important as conditions change. Thus community capacity building for improved governance is of particular value in the absence of a one-size-fits-all formula. Given this, providing communities with the tools to understand their particular biophysical systems and governance processes, manage them adaptively, and respond to changing conditions is ever more critical.

Community fish refuges offer a useful strategy to address the sustainability of fisheries productivity and biodiversity in this system, and our findings suggest that further long-term research is required to isolate the relationship between elements of this strategy and key production and biodiversity outcomes within the system. Research that examines even longer time horizons under which feedbacks from natural and social systems to each other play out will be of particular value. Using robust analytical methods will offer the most useful insights about the function of CFRs specifically and social-ecological systems generally. Further, our findings also reflect the global drivers that integrally shape these fisheries. The sustainability of fish resources in this 
system consequently cannot be addressed solely by CFR management. CFR biomass and biodiversity will continue to be driven, also, by global forces, including the annual flood pulse system, global climate, and El Niño-Southern Oscillation events, and patterns of regional development and dam-building (Kummu and Sarkkula 2008, Lamberts and Koponen 2008, Arias et al. 2014, Ward et al. 2016). Thus, in addition to targeted interventions at the local level, basin-wide management approaches to maintain flood regimes in the face of global environmental changes and basin development remain paramount to protecting fish diversity and productivity.

Responses to this article can be read online at: http://www.ecologyandsociety.org/issues/responses. php/11053

\begin{abstract}
Acknowledgments:
We gratefully acknowledge the community fish refuge committees, communities, and partner NGO staff, who supported data collection on this project. Financial support for this project was provided by the U.S. Agency for International Development (USAID), through the project: Rice Field Fisheries Enhancement project and Cornell University's Atkinson Center for a Sustainable Future Postdoctoral Fellows Program. The contents and opinions expressed herein are those of the authors and do not necessarily reflect the views of USAID or the United States Government. Finally, we thank two anonymous reviewers for their thoughtful and detailed feedback.
\end{abstract}

\section{LITERATURE CITED}

Arias, M. E., T. A. Cochrane, M. Kummu, H. Lauri, G. W. Holtgrieve, J. Koponen, and T. Piman. 2014. Impacts of hydropower and climate change on drivers of ecological productivity of Southeast Asia's most important wetland. Ecological Modelling 272:252-263. https://doi.org/10.1016/j. ecolmodel.2013.10.015

Asian Development Bank. 2012. Rural development for Cambodia: key issues and constraints. Asian Development Bank, Mandaluyong City, Philippines.

Babcock, R. C., N. T. Shears, A. C. Alcala, N. S. Barrett, G. J. Edgar, K. D. Lafferty, T. R. McClanahan, and G. R. Russ. 2010. Decadal trends in marine reserves reveal differential rates of change in direct and indirect effects. Proceedings of the National Academy of Sciences 107:18256-18261. https://doi.org/10.1073/ pnas.0908012107

Baird, I. G. 2000. Integrating community-based fisheries comanagement and protected areas management in Lao PDR: opportunities for advancement and obstacles to implementation. Evaluating Eden Series: Discussion Paper No. 14. International Institute for Environment and Development, London, UK.

Baird, I. G., and M. S. Flaherty. 2005. Mekong river fish conservation zones in southern Laos: assessing effectiveness using local ecological knowledge. Environmental Management 36:439-454. https://doi.org/10.1007/s00267-005-3093-7
Balzer, P., T. Balzer, D. Bartley, X. Choulamany, S. Funge-Smith, H. Guttman, M. Halwart, A. Luo, J. Margraf, E. Meusch, and S. Pon. 2006. Use and availability of aquatic biodiversity in ricebased ecosystems of Southeast Asia. Journal of Food Composition and Analysis 19:765-766. https://doi.org/10.1016/j.jfca.2006.03.008

Baran, E., P. Chheng, V. Ly, J. Nasielski, S. Saray, B. Touch, and J. Tress. 2014. Fish resources in Cambodia (2001-2011). Pages 1-11 in S. Brod and R. Sandoval, editors. Atlas of Cambodia. Save Cambodia's Wildlife, Phnom Penh, Cambodia.

Brooks, A., M. Kim, C. Sieu, V. Sean, and V. Try. 2015. A characterization of community fish refuge typologies in rice field fisheries ecosystems. Handbook: 2015-37. WorldFish, Penang, Malaysia.

Brooks, A., and C. Sieu. 2016. The potential of community fish refuges (CFRs) in rice field agro-ecosystems for improving food and nutrition security in the Tonle Sap region. Program Report: 2016-10. WorldFish, Penang, Malaysia.

Campbell, I. C., C. Poole, W. Giesen, and J. Valbo-Jorgensen. 2006. Species diversity and ecology of Tonle Sap Great Lake, Cambodia. Aquatic Sciences 68:355-373. https://doi.org/10.1007/ $\underline{\mathrm{s} 00027-006-0855-0}$

Chheng, P. 2010. Fish sanctuaries in the Tonle Sap Great Lake (Cambodia). Thesis. Universiti Sains Malaysia, Penang, Malaysia.

Cooke, S. J., E. H. Allison, T. D. Beard, R. Arlinghaus, A. H. Arthington, D. M. Bartley, I. G. Cowx, C. Fuentevilla, N. J. Leonard, K. Lorenzen, et al. 2016. On the sustainability of inland fisheries: finding a future for the forgotten. Ambio 45:753-764. https://doi.org/10.1007/s13280-016-0787-4

Dela Cruz, C. R., C. Lightfoot, B. A. Costa-Pierce, V. R. Carangal, and M. P. Bimbao. 1992. Rice-fish research and development in Asia. The International Center for Living Aquatic Resources Management, Manila, Philippines.

Dodds, W., and M. Whiles. 2010. Freshwater ecology: concepts and environmental applications of limnology. Academic, Burlington, Massachusetts, USA.

Filbee-Dexter, K., C. C. Symons, K. Jones, H. A. Haig, J. Pittman, S. M. Alexander, and M. J. Burke. 2018. Quantifying ecological and social drivers of ecological surprise. Journal of Applied Ecology 55:2135-2146. https://doi.org/10.1111/1365-2664.13171

Fisheries Administration. 2009. Government National Strategic Development Plan 2009-2013. Cambodian Ministry of Agriculture, Forestry, and Fisheries, Phnom Penh, Cambodia.

Fluet-Chouinard, E., S. Funge-Smith, and P. B. McIntyre. 2018. Global hidden harvest of freshwater fish revealed by household surveys. Proceedings of the National Academy of Sciences 115:7623-7628. https://doi.org/10.1073/pnas.1721097115

Gill, D. A., M. B. Mascia, G. N. Ahmadia, L. Glew, S. E. Lester, M. Barnes, I. Craigie, E. S. Darling, C. M. Free, J. Geldmann, et al. 2017. Capacity shortfalls hinder the performance of marine protected areas globally. Nature 543:665-669. https://doi. org/10.1038/nature21708 
Gregory, R., and H. Guttman. 2002. The ricefield catch and rural food security. Pages 1-13 in P. Edwards, D. C. Little, and H. Demaine, editors. Rural aquaculture. CABI, Willingford, UK. https://doi.org/10.1079/9780851995656.0001

Gupta, N., K. Sivakumar, V. B. Mathur, and M. A. Chadwick. 2015. Terrestrial protected areas and managed reaches conserve threatened freshwater fish in Uttarakhand, India. PARKS 21.1. https://doi.org/10.2305/iucn.ch.2014.parks-21-1ng.en

Gurung, T. B., and S. K. Wagle. 2005. Revisiting underlying ecological principles of rice-fish integrated farming for environmental, economical and social benefits. Our Nature 3:1-12. https://doi.org/10.3126/on.v3i1.328

Hap, N., S. Un, and J. Nasielski. 2016. A review of socioeconomic studies in the fisheries sector in Cambodia. Inland Fisheries Research and Development Institute of the Fisheries Administration and WorldFish, Phnom Penh, Cambodia.

Hortle, K. G., S. Lieng, and J. Valbo-Jorgensen. 2004. An Introduction to Cambodia's Inland Fisheries. Mekong River Commission, Phnom Penh.

Hughes, T. P., M. L. Barnes, D. R. Bellwood, J. E. Cinner, G. S. Cumming, J. B. C. Jackson, J. Kleypas, I. A. van de Leemput, J. M. Lough, T. H. Morrison, et al. 2017. Coral reefs in the Anthropocene. Nature 546:82-90. https://doi.org/10.1038/ nature22901

Jensen, J. W. 1990. Comparing fish catches taken with gill nets of different combinations of mesh sizes. Journal of Fish Biology 37:99-104. https://doi.org/10.1111/j.1095-8649.1990.tb05931.x

Joffre, O., M. Kosal, Y. Kura, S. Pich and T. Nao. 2012. Community fish refuges in Cambodia: lesson learned. Lessons Learned Brief 2012-03. WorldFish, Phnom Penh, Cambodia.

Kiwango, Y., G. Moshi, W. Kibasa, and B. Mnaya. 2013. Papyrus wetlands creation, a solution to improve food security and save Lake Victoria. Wetlands Ecology and Management 21:147-154. https://doi.org/10.1007/s11273-013-9286-6

Kummu, M., and J. Sarkkula. 2008. Impact of the Mekong River flow alteration on the Tonle Sap flood pulse. AMBIO 37:185-192. https://doi.org/10.1579/0044-7447(2008)37[185:iotmrf]2.0.co;2

Kura, Y., C. Revenga, E. Hoshino, and G. Mock. 2004. Fishing for answers: making sense of the global fish crisis. World Resources Institute, Washington, D.C., USA.

Laborde, S., A. Fernández, S. C. Phang, I. M. Hamilton, N. Henry, H. C. Jung, A. Mahamat, M. Ahmadou, B. K. Labara, S. Kari, et al. 2016. Social-ecological feedbacks lead to unsustainable lockin in an inland fishery. Global Environmental Change 41:13-25. https://doi.org/10.1016/j.gloenvcha.2016.08.004

Lamberts, D., and J. Koponen. 2008. Flood pulse alterations and productivity of the Tonle Sap ecosystem: a model for impact assessment. AMBIO 37:178-184. https://doi.org/10.1579/0044-7447 (2008)37[178:fpaapo]2.0.co;2

Leslie, H. M., X. Basurto, M. Nenadovic, L. Sievanen, K. C. Cavanaugh, J. J. Cota-Nieto, B. E. Erisman, E. Finkbeiner, G. Hinojosa-Arango, M. Moreno-Baez, et al. 2015. Operationalizing the social-ecological systems framework to assess sustainability.
Proceedings of the National Academy of Sciences 112:5979-5984. https://doi.org/10.1073/pnas.1414640112

Magurran, A. E. 2004. Measuring biological diversity. Blackwell Science, Malden, Massachusetts, USA.

McDermott, G. R., K. C. Meng, G. G. McDonald, and C. J. Costello. 2019. The blue paradox: preemptive overfishing in marine reserves. Proceedings of the National Academy of Sciences 116:5319-5325. https://doi.org/10.1073/pnas.1802862115

McGinnis, M. D., and E. Ostrom. 2014. Social-ecological system framework: initial changes and continuing challenges. Ecology and Society 19(2):30. https://doi.org/10.5751/ES-06387-190230

Minns, C. K., and D. A. Hurley. 1988. Effects of net length and set time on fish catches in gill nets. North American Journal of Fisheries Management 8:216-223. https://doi.org/10.1577/1548-8675 (1988)008<0216:EONLAS > 2.3.CO;2

Miratori, K., and A. Brooks. 2015. Good governance of rice field fishery management. WorldFish, Penang, Malaysia.

Oksanen, J., F. G. Blanchet, M. Friendly, R. Kindt, P. Legendre, D. McGlinn, P. R. Minchin, R. B. O'Hara, G. L. Simpson, P. Solymos, et al. 2019. vegan: Community ecology package. Version 2.5-5. [online] URL: https://cran.r-project.org/package=vegan

Olsson, P., C. Folke, and F. Berkes. 2004. Adaptive comanagement for building resilience in social-ecological systems. Environmental Management 34:75-90. https://doi.org/10.1007/s00267-003-0101-7

Ostrom, E. 2007. A diagnostic approach for going beyond panaceas. Proceedings of the National Academy of Sciences of the United States of America 104:15181-15187. https://doi. org/10.1073/pnas.0702288104

Ostrom, E. 2009. A general framework for analyzing sustainability of social-ecological systems. Science 325:419-422. https://doi.org/10.1126/science.1172133

Pomeroy R. S. and N. L. Andrew. 2011. Small-scale fisheries management: frameworks and approaches for the developing world. CABI, London, UK. https://doi.org/10.1079/9781845936075.0000

Pomeroy, R. S., and F. Berkes. 1997. Two to tango: the role of government in fisheries co-management. Marine Policy 21:465-480. https://doi.org/10.1016/S0308-597X(97)00017-1

Pomeroy, R. S., and M. B. Carlos. 1997. Community-based coastal resource management in the Philippines: a review and evaluation of programs and projects, 1984-1994. Marine Policy 21:445-464. https://doi.org/10.1016/S0308-597X(97)00016-X

Ratner, B. D., E. J. V. Oh, and R. S. Pomeroy. 2012. Navigating change: second-generation challenges of small-scale fisheries comanagement in the Philippines and Vietnam. Journal of Environmental Management 107:131-139. https://doi.org/10.1016/ j.jenvman.2012.04.014

Rouse, D. 1979. Water quality management in pond fish culture. Research and Development Series No. 22. International Center for Aquaculture, Agricultural Experiment Station, Auburn University, Auburn, Alabama, USA.

Sarkar, U. K., A. K. Pathak, L. K. Tyagi, S. M. Srivastava, S. P. Singh, and V. K. Dubey. 2013. Biodiversity of freshwater fish of 
a protected river in India: comparison with unprotected habitat. Revista de Biología Tropical 61:161-172. https://doi.org/10.15517/ rbt.v61i1.10942

Schlüter, M., R. R. J. McAllister, R. Arlinghaus, N. Bunnefeld, K. Eisenack, F. Hölker, E. J. Milner-Gulland, B. Müller, E. Nicholson, M. Quaas, and M. Stöven. 2012. New horizons for managing the environment: a review of coupled social-ecological systems modeling. Natural Resource Modeling 25:219-272. https://doi.org/10.1111/j.1939-7445.2011.00108.x

Society for Ecological Restoration International Science \& Policy Working Group. 2004. The SER primer on ecological restoration. Society for Ecological Restoration, Washington, D.C., USA.

Stata. 2017. Stata statistics/data analysis. StataCorp LP, College Station, Texas, USA.

Thilsted, S. H., A. Thorne-Lyman, P. Webb, J. R. Bogard, R. Subasinghe, M. J. Phillips, and E. H. Allison. 2016. Sustaining healthy diets: the role of capture fisheries and aquaculture for improving nutrition in the post-2015 era. Food Policy 61:126-131. https://doi.org/10.1016/j.foodpol.2016.02.005

Thomas, P., G. Holtgrieve, V. Elliott, K. McCann, B. McMeans, N. Rooney, A. Smits, T. Phanara, M. Cooperman, S. Clark, C. Phen, and S. Chhuoy. 2017. Seasonal increases in fish trophic niche plasticity within a flood-pulse river ecosystem (Tonle Sap Lake, Cambodia). Ecosphere 8:e01881. https://doi.org/10.1002/ $\underline{\text { ecs } 2.1881}$

USAID. 2012. Cambodia HARVEST: Helping Address Rural Vulnerabilities and Ecosystem Stability. Technical Bulletin \#33: How to Fertilize a Fish Pond. USAID, Phnom Penh, Cambodia.

Vogt, J. M., G. B. Epstein, S. K. Mincey, B. C. Fischer, and P. McCord. 2015. Putting the "E" in SES: unpacking the ecology in the Ostrom social-ecological system framework. Ecology and Society 20(1):55. https://doi.org/10.5751/ES-07239-200155

Ward, P. J., M. Kummu, and U. Lall. 2016. Flood frequencies and durations and their response to El Niño Southern Oscillation: global analysis. Journal of Hydrology 539:358-378. https://doi. org/10.1016/j.jhydrol.2016.05.045

Wooldridge, J. 2001. Econometric analysis of cross section and panel data. MIT Press, Cambridge, Massachusetts, USA.

Young, T. P., D. A. Petersen, and J. J. Clary. 2005. The ecology of restoration: historical links, emerging issues and unexplored realms. Ecology Letters 8:662-673. https://doi.org/10.1111/ j.1461-0248.2005.00764.X

Zedler, J. B. 2000. Progress in wetland restoration ecology. Trends in Ecology \& Evolution 15:402-407. https://doi.org/10.1016/ $\underline{\mathrm{S} 0169-5347(00) 01959-5}$

Ziegler, J. P., E. J. Golebie, S. E. Jones, B. C. Weidel and C. T. Solomon. 2017. Social-ecological outcomes in recreational fisheries: the interaction of lakeshore development and stocking. Ecological Applications 27:56-65. https://doi.org/10.1002/ eap. 1433 


\section{Appendix 1: Biophysical and Governance Activities undertaken in the management of}

CFRs.

\begin{tabular}{|c|c|c|}
\hline Categorization & Specific Activity & Specifications/Goals ${ }^{\mathbf{a}}$ \\
\hline \multirow{8}{*}{$\begin{array}{l}\text { Environment- } \\
\text { related activities, } \\
V_{\mathrm{i}, \mathrm{t}-1}\end{array}$} & Building fences & Keep cattle out of CFR \\
\hline & Ecoshelters & Provide fish habitat \\
\hline & Adding fertilizer & $\begin{array}{l}\text { Increase nutrient availability } \\
\text { when } P \text { and K levels too low }\end{array}$ \\
\hline & Adding fingerlings or broodstock & Increase fish recruitment \\
\hline & Adding or removing vegetation & $\begin{array}{l}\text { Achieve ideal degree of } \\
\text { intermediate vegetation } \\
\text { coverage }\end{array}$ \\
\hline & Expanding the CFR & Increase habitat size \\
\hline & Planting flooded forest & Reduce run-off \\
\hline & Purchasing a boat for monitoring and patrols & Reduce illegal fishing \\
\hline \multirow{5}{*}{$\begin{array}{l}\text { Water-quality } \\
\text { related activities, } \\
Q_{i t}\end{array}$} & Adding channels & Increase connectivity \\
\hline & Adding inlets/outlets & Increase connectivity \\
\hline & Adding pump & Increase water level in CFR \\
\hline & Building dam & Increase water level in CFR \\
\hline & Deepening the CFR & Increase habitat size \\
\hline \multirow{5}{*}{$\begin{array}{l}\text { Governance } \\
\text { Meetings, } M_{i t}\end{array}$} & Awareness raising events & Increase knowledge about \\
\hline & & $\begin{array}{l}\text { CFR and its management } \\
\text { amount community }\end{array}$ \\
\hline & Coaching on management skills & Increase knowledge about \\
\hline & & $\begin{array}{l}\text { CFR and its management } \\
\text { among CFR Committee }\end{array}$ \\
\hline & Reflection workshops & $\begin{array}{l}\text { Facilitate CFR Committee } \\
\text { reflection and planning }\end{array}$ \\
\hline Governance & Building a new CFR & Expansion of CFR domain \\
\hline \multirow[t]{6}{*}{ Activities, $A_{i t}$} & Demarcating the boundaries of the CFR & $\begin{array}{l}\text { Reduce illegal fishing, } \\
\text { establish jurisdiction }\end{array}$ \\
\hline & Adding signs, paths, guard infrastructure & Reduce illegal fishing \\
\hline & Holding elections of CFR Committees & $\begin{array}{l}\text { Establish governance } \\
\text { structure }\end{array}$ \\
\hline & Establishing bylaws & $\begin{array}{l}\text { Establish governance } \\
\text { structure }\end{array}$ \\
\hline & Holding events & Establish CFR governance \\
\hline & $\begin{array}{l}\text { Integrating CFR actions into broader } \\
\text { community investment plans }\end{array}$ & Increase CFR sustainability \\
\hline
\end{tabular}

${ }^{\mathrm{a}}$ Hortle et al., 2004; Joffre et al., 2012; Miratori and Brooks, 2015; Brooks and Sieu, 2016 


Mean SD Median Min Max N

Biomass $(\mathrm{kg} / \mathrm{m} 2)$

Annual

February

May

November

Species Richness

$\begin{array}{llllll}45.3 & 40.3 & 31.2 & 4.4 & 306.1 & 160 \\ 63.4 & 69.7 & 39.2 & 4.6 & 427.6 & 119 \\ 52.2 & 55.0 & 34.5 & 2.2 & 322.6 & 119 \\ 36.9 & 33.0 & 27.1 & 2.8 & 210.6 & 160\end{array}$

Annual

February

May

November

Area (m2) of gill net submerged

Water temperature (C)

Mean

Share with temperature $>=32 \mathrm{C}$

$\mathrm{pH}$

Mean

Share in ideal range (6.5-8.5)

Maximum phosphate level in calendar year

CFR Activities

Number related to water quality

Number related to CFR environment

Number of governance activities

Number of meetings, coaching and

awareness activities

Total funds raised by CFR committee (USD)

CFR area during dry season (m2)

Number of households in CFR zone of

influence

$\begin{array}{rrrrrr}6.74 & 0.78 & 6.70 & 5 & 9 & 160 \\ 0.88 & 0.33 & 1 & 0 & 1 & 160\end{array}$

$\begin{array}{llllll}0.7 & 1.1 & 0.5 & 0 & 12.5 & 160\end{array}$

$\begin{array}{llllll}14.6 & 5.2 & 14.5 & 3.0 & 31.0 & 160\end{array}$

$\begin{array}{llllll}15.5 & 5.9 & 15.0 & 4.0 & 32.0 & 119\end{array}$

$\begin{array}{llllll}12.1 & 5.3 & 11.0 & 1.0 & 31.0 & 119\end{array}$

$\begin{array}{llllll}16.5 & 6.7 & 17.0 & 3.0 & 38.0 & 160\end{array}$

$\begin{array}{llllll}22.9 & 8.5 & 22.4 & 7.3 & 45 & 160\end{array}$

$\begin{array}{rrrrrr}29.8 & 2.0 & 29.6 & 25.5 & 38 & 153 \\ 0.4 & 0.5 & 0 & 0 & 1 & 160\end{array}$

Province (\% of CFRs in each)

$\begin{array}{rrrrrr}0.6 & 0.8 & 0 & 0 & 3 & 120 \\ 2.4 & 1.3 & 2 & 0 & 5 & 120 \\ 3.1 & 1.5 & 3 & 0 & 7 & 120 \\ 4.9 & 1.7 & 5 & 1 & 9 & 120 \\ & & & & & \\ 469 & 953 & 109 & 0 & 6862 & 120 \\ 1.9 & 2.5 & 0.8 & 0 & 10 & 40 \\ 860 & 697.3 & 617.5 & 105 & 3042 & 40\end{array}$


Battambang

Kampong Thom

Pursat

Siem Reap

Category ( $\%$ of CFRs in each)

Reservoir for irrigation in upland area

Pond within agricultural area, land not prone to flood

Pond within agricultural area, land prone to flood

Demarcated area in larger water body

Agro-ecological zone (\% of CFRs in each)

Lowland deepwater rice

Rainfed lowland rice

Upland irrigated

Upland rainfed rice or other crop

$\begin{array}{llllll}17 \% & 38 \% & 0 \% & 0 \% & 100 \% & 40 \\ 28 \% & 45 \% & 0 \% & 0 \% & 100 \% & 40 \\ 25 \% & 43 \% & 0 \% & 0 \% & 100 \% & 40 \\ 30 \% & 46 \% & 0 \% & 0 \% & 100 \% & 40\end{array}$

$17 \% \quad 38 \% \quad 0 \% \quad 0 \% \quad 100 \% \quad 40$

$\begin{array}{llllll}35 \% & 48 \% & 0 \% & 0 \% & 100 \% & 40\end{array}$

$25 \% \quad 43 \% \quad 0 \% \quad 0 \% \quad 100 \% \quad 40$

$22 \% \quad 42 \% \quad 0 \% \quad 0 \% \quad 100 \% \quad 40$

$\begin{array}{llllll}25 \% & 43 \% & 0 \% & 0 \% & 100 \% & 40 \\ 20 \% & 40 \% & 0 \% & 0 \% & 100 \% & 40 \\ 17 \% & 38 \% & 0 \% & 0 \% & 100 \% & 40 \\ 38 \% & 49 \% & 0 \% & 0 \% & 100 \% & 40\end{array}$

Note: Summary statistics by year available upon request. 
Appendix 3: Summary of results.

\begin{tabular}{|c|c|c|c|c|}
\hline $\begin{array}{l}\text { Relationship \& } \\
\text { Table }\end{array}$ & Model & $\begin{array}{l}\text { Number } \\
\text { of time } \\
\text { points }\end{array}$ & Findings & Interpretation \\
\hline $\begin{array}{l}\text { Relationship 1: } \\
\text { Site } \\
\text { characteristics } \\
\text { Table } 1\end{array}$ & $\begin{array}{l}\text { Linear regression } \\
\text { (cross-sectional) }\end{array}$ & 1 & $\begin{array}{l}\text { Site characteristics, including } \\
\text { province, agroecological zone, and } \\
\text { surface area, were significantly } \\
\text { associated with biomass and species } \\
\text { diversity. Year was significantly } \\
\text { associated with species richness. CFR } \\
\text { type was significantly associated with } \\
\text { biomass. }\end{array}$ & $\begin{array}{l}\text { CFR sites are heterogeneous. The differences } \\
\text { between CFRs that we observe affect biomass and } \\
\text { biodiversity within them. Further, analyses should } \\
\text { include strong controls by site to account for these } \\
\text { differences when assessing the underlying ecological } \\
\text { and intervention dynamics. }\end{array}$ \\
\hline $\begin{array}{l}\text { Relationship 2: } \\
\text { Habitat quality } \\
\text { Table } 2\end{array}$ & $\begin{array}{l}\text { Linear regression } \\
\text { (panel), fixed } \\
\text { effects for } \\
\text { Community Fish } \\
\text { Refuge }\end{array}$ & $\begin{array}{l}13 \text {, every } 3 \\
\text { months }\end{array}$ & $\begin{array}{l}\text { Species richness and biomass were } \\
\text { associated with month. In the previous } \\
\text { period, high water temperature and } \\
\text { ideal pH are negatively associated and } \\
\text { Secchi depth is positively associated } \\
\text { with biomass. }\end{array}$ & $\begin{array}{l}\text { The flood pulse and other seasonal factors play a } \\
\text { strong role in CFR system dynamics. This dynamism } \\
\text { may shape the appropriateness and effectiveness of } \\
\text { biophysical and governance changes. Independently } \\
\text { of temporal cycles, water quality was associated with } \\
\text { fish biomass. }\end{array}$ \\
\hline $\begin{array}{l}\text { Relationship 4: } \\
\text { Governance } \\
\text { actions } \\
\text { Table } 4\end{array}$ & $\begin{array}{l}\text { Linear regression } \\
\text { (annual panel), } \\
\text { fixed effects for } \\
\text { Community Fish } \\
\text { Refuge }\end{array}$ & 3 & $\begin{array}{l}\text { Governance meetings were positively } \\
\text { associated and governance activities } \\
\text { were negatively associated with } \\
\text { species richness. Fundraising to } \\
\text { support governance activities was } \\
\text { positively associated with biomass. }\end{array}$ & $\begin{array}{l}\text { We find some evidence of associations between } \\
\text { governance activities and fundraising with species } \\
\text { richness and biomass, respectively. Although the } \\
\text { mechanism through which these operate is not clear, } \\
\text { it suggests an identifiable role of governance } \\
\text { improvements in fishery productivity and diversity. }\end{array}$ \\
\hline
\end{tabular}


Appendix 4: Relationships between CFR characteristics and biomass and species richness, by year

\begin{tabular}{|c|c|c|c|c|c|c|c|c|}
\hline & \multicolumn{4}{|c|}{ (ln) Biomass } & \multicolumn{4}{|c|}{ Species Richness } \\
\hline & 2012 & 2013 & 2014 & 2015 & 2012 & 2013 & 2014 & 2015 \\
\hline $\begin{array}{l}\text { 1=Community } \\
\text { Pond Without }\end{array}$ & & & & & & & & \\
\hline Flooding* & $\begin{array}{l}0.245 \\
(0.409)\end{array}$ & $\begin{array}{l}0.126 \\
(0.424)\end{array}$ & $\begin{array}{l}0.638 * \\
(0.355)\end{array}$ & $\begin{array}{l}0.541 \\
(0.415)\end{array}$ & $\begin{array}{c}2.641 \\
(4.103)\end{array}$ & $\begin{array}{c}1.546 \\
(2.372)\end{array}$ & $\begin{array}{l}0.650 \\
(2.400)\end{array}$ & $\begin{array}{l}0.874 \\
(2.288)\end{array}$ \\
\hline $\begin{array}{l}\text { 1= Community } \\
\text { Pond with }\end{array}$ & & & & & & & & \\
\hline Flooding* & $\begin{array}{c}0.0822 \\
(0.598)\end{array}$ & $\begin{array}{c}0.464 \\
(0.614)\end{array}$ & $\begin{array}{l}0.898 * \\
(0.499)\end{array}$ & $\begin{array}{l}0.396 \\
(0.600)\end{array}$ & $\begin{array}{c}3.106 \\
(6.260)\end{array}$ & $\begin{array}{c}2.631 \\
(3.540)\end{array}$ & $\begin{array}{l}2.841 \\
(3.273)\end{array}$ & $\begin{array}{l}2.964 \\
(3.293)\end{array}$ \\
\hline $1=$ Segment of & & & & & & & & \\
\hline Large Water Body* & $\begin{array}{c}0.565 \\
(0.472)\end{array}$ & $\begin{array}{c}0.649 \\
(0.489)\end{array}$ & $\begin{array}{l}0.297 \\
(0.392)\end{array}$ & $\begin{array}{l}0.167 \\
(0.469)\end{array}$ & $\begin{array}{c}6.668 \\
(4.799)\end{array}$ & $\begin{array}{c}3.493 \\
(2.758)\end{array}$ & $\begin{array}{l}2.226 \\
(2.564)\end{array}$ & $\begin{array}{l}2.826 \\
(2.554)\end{array}$ \\
\hline 1= Kampong Thom & & & & & & & & \\
\hline Province $^{\wedge}$ & $\begin{array}{l}0.143 \\
(0.377)\end{array}$ & $\begin{array}{c}0.220 \\
(0.382)\end{array}$ & $\begin{array}{c}0.475 \\
(0.309)\end{array}$ & $\begin{array}{l}0.252 \\
(0.361)\end{array}$ & $\begin{array}{c}2.695 \\
(3.814)\end{array}$ & $\begin{array}{c}2.818 \\
(2.114)\end{array}$ & $\begin{array}{c}3.116 \\
(2.083)\end{array}$ & $\begin{array}{c}2.800 \\
(2.044)\end{array}$ \\
\hline 1= Pursat & & & & & & & & \\
\hline Province $^{\wedge}$ & $\begin{array}{l}0.940 * * \\
(0.359)\end{array}$ & $\begin{array}{c}0.419 \\
(0.367)\end{array}$ & $\begin{array}{l}0.870 * * * \\
(0.296)\end{array}$ & $\begin{array}{c}0.234 \\
(0.342)\end{array}$ & $\begin{array}{l}8.262 * * \\
(3.486)\end{array}$ & $\begin{array}{l}5.487^{* *} \\
(1.995)\end{array}$ & $\begin{array}{l}8.878 * * * \\
(1.951)\end{array}$ & $\begin{array}{l}7.712^{* * *} \\
(1.922)\end{array}$ \\
\hline 1= Siem Riep & & & & & & & & \\
\hline Province $^{\wedge}$ & $\begin{array}{l}0.918^{* *} \\
(0.377)\end{array}$ & $\begin{array}{c}0.734 * \\
(0.384)\end{array}$ & $\begin{array}{l}0.830 * * \\
(0.306)\end{array}$ & $\begin{array}{c}0.361 \\
(0.355)\end{array}$ & $\begin{array}{c}4.557 \\
(3.745)\end{array}$ & $\begin{array}{c}2.146 \\
(2.142)\end{array}$ & $\begin{array}{l}0.596 \\
(2.081)\end{array}$ & $\begin{array}{l}0.733 \\
(1.981)\end{array}$ \\
\hline $\begin{array}{l}\text { 1= Rainfed } \\
\text { lowland rice AEZ }\end{array}$ & $\begin{array}{l}0.879 * * \\
(0.368)\end{array}$ & $\begin{array}{l}0.125 \\
(0.380)\end{array}$ & $\begin{array}{l}0.381 \\
(0.303)\end{array}$ & $\begin{array}{l}0.189 \\
(0.350)\end{array}$ & $\begin{array}{l}6.581^{*} \\
(3.578)\end{array}$ & $\begin{array}{l}1.202 \\
(2.094)\end{array}$ & $\begin{array}{l}1.645 \\
(2.001)\end{array}$ & $\begin{array}{l}1.394 \\
(1.971)\end{array}$ \\
\hline $\begin{array}{l}\text { 1= Upland } \\
\text { Irrigated AEZ }\end{array}$ & $\begin{array}{c}0.277 \\
(0.479)\end{array}$ & $\begin{array}{c}0.624 \\
(0.493)\end{array}$ & $\begin{array}{l}0.388 \\
(0.396)\end{array}$ & $\begin{array}{l}0.509 \\
(0.462)\end{array}$ & $\begin{array}{c}4.162 \\
(5.186)\end{array}$ & $\begin{array}{c}3.901 \\
(2.868)\end{array}$ & $\begin{array}{l}1.328 \\
(2.640)\end{array}$ & $\begin{array}{l}2.686 \\
(2.638)\end{array}$ \\
\hline $\begin{array}{l}\text { 1= Upland Crop / } \\
\text { Rainfed Rice AEZ }\end{array}$ & $\begin{array}{l}0.357 \\
(0.430)\end{array}$ & $\begin{array}{c}0.324 \\
(0.443)\end{array}$ & $\begin{array}{l}0.484 \\
(0.354)\end{array}$ & $\begin{array}{l}0.193 \\
(0.419)\end{array}$ & $\begin{array}{l}0.136 \\
(4.465)\end{array}$ & $\begin{array}{c}0.627 \\
(2.525)\end{array}$ & $\begin{array}{l}1.779 \\
(2.305)\end{array}$ & $\begin{array}{l}1.775 \\
(2.340)\end{array}$ \\
\hline $\begin{array}{l}\text { (In) Number of } \\
\text { Households in CFR }\end{array}$ & & & & & & & & \\
\hline Catchment Area & $\begin{array}{c}0.0319 \\
(0.156)\end{array}$ & $\begin{array}{l}0.0542 \\
(0.160)\end{array}$ & $\begin{array}{c}0.175 \\
(0.128)\end{array}$ & $\begin{array}{c}0.173 \\
(0.149)\end{array}$ & $\begin{array}{l}0.315 \\
(1.563)\end{array}$ & $\begin{array}{c}0.261 \\
(0.918)\end{array}$ & $\begin{array}{c}1.430 \\
(0.860)\end{array}$ & $\begin{array}{c}1.184 \\
(0.839)\end{array}$ \\
\hline $\begin{array}{l}\text { (In) CFR Surface } \\
\text { Area in Dry Season }\end{array}$ & & & & & & & & \\
\hline (Ha) & $\begin{array}{l}0.0107 \\
(0.243)\end{array}$ & $\begin{array}{c}0.330 \\
(0.246)\end{array}$ & $\begin{array}{c}0.280 \\
(0.210)\end{array}$ & $\begin{array}{l}0.554^{* *} \\
(0.255)\end{array}$ & $\begin{array}{l}3.307 \\
(2.500)\end{array}$ & $\begin{array}{l}1.540 \\
(1.478)\end{array}$ & $\begin{array}{l}0.496 \\
(1.573)\end{array}$ & $\begin{array}{l}0.595 \\
(1.603)\end{array}$ \\
\hline
\end{tabular}


Area of Gill Net

Submerged During

Biomonitoring

Sampling $\left(m^{\wedge} 2\right)$

$\begin{array}{llll}0.118 & 0.126 & 0.114 & 0.147 \\ (0.148) & (0.0919) & (0.0987) & (0.0973)\end{array}$

Constant

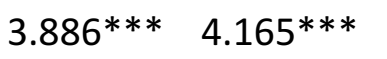

$4.702 * *$

$4.761 * * *$

16.06

$16.94 * *$

$20.72 * * *$

$16.82 * * *$

$(1.128$

(1.168)

(0.945) (1.085)

(11.12)

(6.531) (6.147)

(5.920)

Observations

40

40

40

40

40

40

40

40

$\mathrm{R}$ squared

0.565

0.377

0.638

0.516

$0.371 \quad 0.414$

0.651

0.636

Notes: *Reference category is "Irrigation Reservoir"; ^Reference category is Battambong Province; Reference category is "lowland deepwater rice" Agro Eco Zone. Reference year is 2012.

Standard errors in parenthesesSignificance levels: ${ }^{* *} p<0.01, * * p<0.05, *$ $p<0.1$ 
Appendix 5. Relationship between CFR water quality indicators and previous year habitat management actions--Alternate specifications

\begin{tabular}{|c|c|c|c|c|c|c|}
\hline & \multicolumn{3}{|c|}{ Water temperature $>=32 \mathrm{C}$} & \multicolumn{3}{|c|}{$\mathrm{pH}$ range 6.58 .5} \\
\hline & OLS FE & Logistic & Probit & OLS FE & Logistic & Probit \\
\hline $\begin{array}{l}\text { Number of CFR environment activities } \\
\text { (lagged) }\end{array}$ & $\begin{array}{l}0.00712 \\
(0.0151)\end{array}$ & $\begin{array}{l}0.00429 \\
(0.139)\end{array}$ & $\begin{array}{l}0.00316 \\
(0.0794)\end{array}$ & $\begin{array}{l}0.0364 \\
(0.0258)\end{array}$ & $\begin{array}{l}0.0693 \\
(0.0958)\end{array}$ & $\begin{array}{l}0.0421 \\
(0.0580)\end{array}$ \\
\hline $\begin{array}{l}\text { Number of water quality activities } \\
\text { (lagged) }\end{array}$ & $\begin{array}{c}0.0188 \\
(0.0280)\end{array}$ & $\begin{array}{c}0.149 \\
(0.261)\end{array}$ & $\begin{array}{c}0.0744 \\
(0.143)\end{array}$ & $\begin{array}{c}0.0743^{*} \\
(0.0391)\end{array}$ & $\begin{array}{l}0.351^{* *} \\
(0.149)\end{array}$ & $\begin{array}{r}0.213^{* *} \\
(0.0909)\end{array}$ \\
\hline Year=2015 & $\begin{array}{c}0.0705^{*} \\
(0.0416)\end{array}$ & $\begin{array}{l}0.808 * * \\
(0.389)\end{array}$ & $\begin{array}{l}0.509 * * \\
(0.209)\end{array}$ & $\begin{array}{l}0.0855^{*} \\
(0.0507)\end{array}$ & $\begin{array}{l}0.408^{*} \\
(0.246)\end{array}$ & $\begin{array}{l}0.242 \\
(0.149)\end{array}$ \\
\hline May & $\begin{array}{l}0.263 * * * \\
(0.0478)\end{array}$ & $\begin{array}{l}2.804 * * * \\
(0.758)\end{array}$ & $\begin{array}{l}1.470 * * * \\
(0.333)\end{array}$ & $\begin{array}{c}0.163^{* *} \\
(0.0610)\end{array}$ & $\begin{array}{c}0.678 * * \\
(0.324)\end{array}$ & $\begin{array}{c}0.423^{* *} \\
(0.201)\end{array}$ \\
\hline August & $\begin{array}{l}0.138 * * * \\
(0.0404)\end{array}$ & $\begin{array}{l}2.048 * * * \\
(0.776)\end{array}$ & $\begin{array}{l}1.000 * * * \\
(0.345)\end{array}$ & $\begin{array}{l}0.100 \\
(0.0657)\end{array}$ & $\begin{array}{l}0.469 \\
(0.345)\end{array}$ & $\begin{array}{l}0.277 \\
(0.208)\end{array}$ \\
\hline November & $\begin{array}{c}0.0250 \\
(0.0176)\end{array}$ & & & $\begin{array}{l}0.0750 \\
(0.0640)\end{array}$ & $\begin{array}{l}0.344 \\
(0.339)\end{array}$ & $\begin{array}{l}0.204 \\
(0.206)\end{array}$ \\
\hline Constant & $\begin{array}{l}0.0553 \\
(0.0380)\end{array}$ & $\begin{array}{l}3.264 * * * \\
(0.787)\end{array}$ & $\begin{array}{l}1.746^{* * *} \\
(0.350)\end{array}$ & $\begin{array}{l}0.543^{* * *} \\
(0.0723)\end{array}$ & $\begin{array}{l}0.378 \\
(0.349)\end{array}$ & $\begin{array}{l}0.242 \\
(0.212)\end{array}$ \\
\hline Observations & 320 & 240 & 240 & 320 & 320 & 320 \\
\hline R squared & 0.161 & & & 0.086 & & \\
\hline Number of CFRs & 40 & & & 40 & & \\
\hline
\end{tabular}

Robust standard errors in parentheses. ${ }^{* * *} \mathrm{p}<0.01,{ }^{* *} \mathrm{p}<0.05,{ }^{*} \mathrm{p}<0.1$. Reference year is 2014. Reference month is February. OLS FE columns report Table 3 values for reference. Logistic and Probit columns report marginal effects. During November and February, all water temperature values >=32C. 